\title{
HUBUNGAN PENGETAHUAN DENGAN SIKAP IBU TENTANG IMUNISASI DIFTERI PADA ANAK BALITA DI DESA JATIWATES KECAMATAN TEMBELANG KABUPATEN JOMBANG
}

\author{
Riska Aprilia $^{1}$, Herlina ${ }^{1}$, Titiek Idayanti ${ }^{1}$, Vera Virgia $^{1}$, Anik Yuliani ${ }^{1}$ \\ ${ }^{1}$ STIKES Dian Husada Mojokerto \\ *Correspondence: \\ Riska Aprilia \\ Email: riez_wea@yahoo.com
}

\begin{abstract}
Background: Difteri adalah penyakit akibat terjangkit bakteri yang bersumber dari corynebacterium diphtheriae. Anak-anak yang berumur satu sampai sepuluh tahun sangat peka terhadap penyakit ini. Dalam masyarakat, banyak ibu yang mempunyai balita yang beranggapan bahwa orang dewasa tidak membutuhkan imunisasi difteri karena ibu yang mempunyai balita tidak mungkin tertular atau terkena penyakit difteri.

Purpose: Penelitian ini bertujuan untuk mengetahui hubungan pengetahuan dengan sikap ibu tentang imunisasi difteri pada anak balita. Method: Penelitian yang digunakan adalah penelitian analitik korelasi. Pada penelitian ini populasinya sebanyak 221 orang. dengan sampel sebagian masyarakat di Desa Jatiwates Kecamatan Tembelang Kabupaten Jombang sebanyak 55 orang, pengambilan sampel secara Cluster Random Sampling, instrumen yang digunakan adalah kuesioner, analisa data dilakukan melalui tahap editing, coding, scoring dan tabulasing kemudian diuji menggunakan uji normalitas.

Results: Hasil penelitian didapatkan bahwa nilai rerata pengetahuan responden sebesar 13.29. Diketahui bahwa terdapat 24 reponden responden yang mempunyai yang memiliki pengetahuan kurang dan bersikap negatif sebanyak 20 responden $(83,3 \%) \rho=0,007<0,05$. Ada hubungan pengetahuan dengan sikap ibu tentang imunisasi difteri pada anak balita di Desa Jatiwates Kecamatan Tembelang Kabupaten Jombang.

Conclusion: Tenaga Kesehatan diharapkan meningkatkan penyuluhan tentang imunisasi difteri dan memberikan dorongan pada ibu tentang pentingnya mendapatkan imunisasi difteri. Ibu dapat mengakses informasi tentang imunisasi difteri baik melalui media massa maupun media elektronik sehingga ibu mengerti dan mempunyai persepsi positif tentang imunisasi difteri dan dapat termotivasi untuk mengikuti imunisasi difteri.
\end{abstract}

Key words: Pengetahuan, sikap, ibu, imunisasi difteri

\section{PENDAHULUAN}

Difteri adalah penyakit akibat terjangkit bakteri yang bersumber dari corynebacterium diphtheriae. Penyakit ini merupakan penyakit mengerikan di mana masa lalu sering menyebabkan kematian dan sampai saat ini masih mewabah di negara yang belum berkembang. Orang yang selamat dari penyakit ini menderita kelumpuhan otot tertentu dan kerusakan permanen pada jantung dan ginjal. Anakanak yang berumur satu sampai sepuluh tahun sangat peka terhadap penyakit ini. Kuman difteri disebarkan oleh menghirup cairan dari mulut atau hidung orang yang terinfeksi, dari jari-jari atau handuk yang 
terkontaminasi, dan dari susu yang terkontaminasi penderita (Rianita, 2012). Dalam masyarakat, banyak ibu yang mempunyai balita yang beranggapan bahwa orang dewasa tidak membutuhkan imunisasi difteri karena ibu yang mempunyai balita tidak mungkin tertular atau terkena penyakit difteri. Sikap yang negatif tersebut mendorong ibu yang mempunyai balita tidak termotivasi untuk mengikuti program imunisasi difteri yang dicanangkan oleh pemerintah. Padahal kenyataan yang ada penderita difteri terbanyak diderita oleh orang dewasa sehingga menimbulkan kematian. Selain itu, ketidakmauan ibu yang mempunyai balita untuk mengikuti imunisasi difteri dikarenakan ibu yang mempunyai balita takut dengan proses penyuntikan. Hal tersebut menyebabkan cakupan imunisasi difteri pada orang dewasa lebih rendah dibandingkan balita (Kholifah, 2010).

Menurut WHO tahun 2012 mencatat wabah difteri di dunia mencapai $11,3 \%$ dari 1/100.000 jumlah penduduk. Indonesia, wabah difteri muncul kembali sejak tahun 2001 di Cianjur, Semarang, Tasikmalaya, Garut, dan Jawa Timur dengan case fatality rate (CFR) 11,7$31,9 \%$. Dengan adanya pencanangan sub PIN difteri pada tahun ini diharapkan di tahun mendatang tingkat kekebalan anak semakin kuat dan angka kasus difteri semakin menurun, terhitung sampai dengan 20 Oktober 2012, jumlah kasus difteri di Jawa Timur mencapai 710 penderita dan 28 diantaranya meninggal dunia. Penyakit difteri sudah menyerang di 38 Kabupaten/kota di Jawa Timur sejak tahun 2011 sampai 2012. Pada tahun 2011, jumlah kasus difteri sebanyak 664 penderita dan 20 diantaranya meninggal dunia. Pada tahun 2011, insiden rate tertinggi di Kota Malang. Sedangkan pada tahun 2012, kasus terbanyak di Kabupaten Situbondo yaitu 113 kasus dan yang meninggal sebanyak 7, disusul Kabupaten Jombang 87 kasus dan yang meninggal 11 orang (Dinkes Jatim, 2012). Hasil penelitian cahyani di Kabupaten madiun tahun 2013 pada 148 responden di dapatkan $67 \%$ tidak mengikuti pelaksanaan imunisasi difteri. Cakupan imunisasi difteri di Kabupaten Jombang mencapai 64\%, target pemerintah Jombang dalam imunisasi difteri adalah 90\% (Dinkes Jombang, 2013) cakupan tertinggi imunisasi difteri tinggi terdapat di Wilayah Kerja Puskesmas Mojoagung sebesar 78\% sedangkan terendah terletak di Puskesmas Kudu yang hanya mencapai $23 \%$.

Faktor yang mempengaruhi pengetahuan masyarakat tentang difteri diantaranya umur, pendidikan, pekerjaan, informasi, yang berdampak pada ketidak ikut sertaan masyarakat dalam imunisasi difteri, di samping itu sikap yang negatif masyarakat bahwa dirinya sehat tidak perlu melakukan imunisasi menyebabkan kurangnya minat masyarakat mengikuti PIN difteri. Umumnya difteri dapat dicegah melalui vaksinasi pada bayi, anak-anak, remaja, dan orang dewasa. Dalam masyarakat banyak ibu yang mempunyai balita yang beranggapan bahwa orang dewasa tidak membutuhkan imunisasi difteri karena ibu yang mempunyai balita tidak mungkin tertular atau terkena penyakit difteri. (Kholifah, 2010).

Langkah yang dapat dilakukan agar ibu yang mempunyai balita menyadari akan bahaya dari penyakit difteri yaitu melalui kegiatan penyuluhan oleh petugas kesehatan khususnya perawat dengan menyebarkan leafled dan konseling pada ibu yang mempunyai balita tentang 
pentingnya vaksin difteri (Pharmlolita, 2012). Selain itu dalam memberikan asuhan kepada pasien, pendekatan yang dilakukan lebih cenderung kepada bentuk pelayanan promotif. Pelaksanaan Komunikasi Informasi dan Edukasi (KIE) kepada ibu yang mempunyai balita dengan materimateri mengenai penyakit difteri (Sulistyawati, 2009). Upaya pemerintah untuk menurunkan penyakit difteri dengan cara ORI (Outbreak Response Immunization). Kegiatan ini merupakan bagian dari sub Pekan Imunisasi Nasional. Pemberian imunisasi DPT merupakan vaksin mati, sehingga untuk mempertahankan kadar antibodi menetap tinggi di atas ambang pencegahan, kelengkapan ataupun pemberian imunisasi ulangan sangat diperlukan. Imunisasi DPT lima kali harus dipatuhi sebelum anak berumur 6 tahun. Apabila belum pernah mendapat DPT, diberikan imunisasi primer DPT tiga kali dengan interval masing-masing 4 minggu (Pharmlolita, 2012).

\section{METODE DAN BAHAN}

Dalam penelitian ini jenis penelitian yang digunakan adalah penelitian analitik korelasi dengan rancangan penelitiannya cross sectional. Peneliti menggunakan desain tersebut karena ingin mengetahui hubungan pengetahuan dengan sikap ibu tentang imunisasi difteri pada anak balita di Desa Jatiwates Kecamatan Tembelang Kabupaten Jombang.

Pada penelitian ini populasinya adalah semua ibu yang mempunyai balita di Desa Jatiwates Kecamatan Tembelang Kabupaten Jombang sebanyak 221 orang. Pada penelitian ini sampelnya adalah sebagian masyarakat di Desa Jatiwates Kecamatan Tembelang Kabupaten
Jombang sebanyak 55 orang, yang didapat dari $25 \%$ dari total populasi. Kriteria Sampel (kriteria inklusi) dalam penelitian ini adalah ibu balita yang bersedia menjadi responden, ibu balita yang bisa baca tulis, ibu balita yang berada di Desa Jatiwates Kecamatan Tembelang Kabupaten Jombang. Pada penelitian ini pengambilan sampel secara Cluster Random Sampling. Cluster random sampling adalah teknik pengambilan sampel berdasarkan tingkatan kelas atau kelompok (Sugiyono, 2010). Pada peneliti ini penelitian mengambil sampel perdusun secara acak sebagai perwakilan sampel yang akan di teliti.

Waktu dalam penelitian ini di mulai pada bulan Oktober 2014 sampai dengan ujian akhir pada bulan Juni 2015. Pada penelitian ini sebelum dilakukan penelitian, peneliti harus mendapatkan izin dari bagian akademik program studi ilmu keperawatan STIKES Dian Husada Mojokerto untuk melakukan studi pendahuluan bersamaan dengan diberikannya surat pengantar yang ditunjukkan kepada kepala Desa Jatiwates Kecamatan Tembelang Kabupaten Jombang. Dengan surat pengantar tersebut peneliti miminta izin kepada kepala Desa Jatiwates Kecamatan Tembelang Kabupaten Jombang untuk melakukan studi pendahuluan sebagai langkah awal dari penelitian. Kemudian peneliti mendapatkan surat balasan dari kepala Desa Jatiwates untuk melakukan studi pendahuluan. Peneliti melakukan prosedur pengumpulan data sebagai berikut:

Peneliti mendatangi rumah calon responden satu persatu setelah itu peneliti menjelaskan maksud dan tujuan datang kerumah responden. Informed consent berisi penjelasan tentang penelitian, tujuan, manfaat, prosedur yang diterima dan 
lamanya penelitian kepada responden. Pada bagian akhir berisi tentang lembar persetujuan responden mengikuti penelitian. Responden bebas melakukan pilihan apakah mau berpartisipasi atau tidak setelah diberikan informasi tentang penelitian, tanpa ada unsur paksaan. Lembar persetujuan menjadi responden tersebut ditandatangani oleh calon responden sendiri. Kemudian responden diberi penjelasan tentang judul penelitian, tujuan, manfaat, prosedur penelitian, perlakuan yang akan diberikan kepada responden. Peneliti memberikan lembar kuesioner kepada responden yang mau bersedia menjadi responden. Peneliti memberikan lembar kuesioner kepada Responen di berikan waktu 20 menit untuk menjawab pertanyaan dengan jumlah pertayaan 40 soal yang di berikan responden. Peneliti menunggu responden untuk menjawab pertanyaan yang diberikan. Setelah selesai menjawab pertanyaan tersebut lembar kuesioner di berikan kepada peneliti untuk di teliti apakah semua pertayaan terjawab semua atau tidak. Setelah terjawab semua peneliti meminta ijin pulang dan tak lupa berterima kasih mau berpartisipasi dalam penelitian yang di adakan peneliti.

Intrumen yang digunakan untuk mengumpulkan data pada penelitian ini dengan menggunakan lembar kuesioner untuk mengetahui hubungan pengetahuan dengan sikap ibu tentang imunisasi difteri pada anak balita. Untuk menguji valid dan realiabilitas peneliti menyebarkan kuesioner sebayank 15 responden ditempat yang berbeda. Di mana peneliti memberikan lembar kuesioner tentang pengetahuan berjumlah 20 pertanyaan dan lembar kuesioner tentang sikap berjumlah 20 pertanyaan. Jadi jumlah keseluruhan pertanyaan hubungan pengetahuan dengan sikap berjumlah 40 pertayaan diberikan waktu 20 menit untuk menjawab pertanyaan. Dengan cara pengisian yaitu responden memberi tanda cek list $(\sqrt{ })$ pada jawaban yang telah disediakan. Setelah lembar kuesioner terkumpul peneliti menguji 40 soal tersebut apakah valid atau tidak dan dari 40 soal tersebut hasil yang didapatkan valid dengan menggunakan uji alfa cronbach yang ada di program SPSS. Di yatakan valid bila nilai $\leq$ alfa $(0,05)$ sehingga semua butir soal di nyatakan valid. Dari uji reabilitas dengan rumus alfa cronbach jika nilai alfa cronbach $\geq 0,60$ maka instrumen diyatakan layak di gunakan dalam pengumpulan data.

\section{HASIL PENELITIAN}

\section{Karakteristik Responden Berdasarkan Pengetahuan Ibu tentang Imunisasi Difteri.}

Tabel 1. Karakteristik Responden Berdasarkan Pengetahuan Ibu tentang Imunisasi Difteri di Puskesmas Jatiwates Kecamatan Tembelang Kabupaten Jombang.

\begin{tabular}{|l|r|}
\hline \multicolumn{1}{|c|}{ Pengetahuan } \\
\hline Mean & 63.73 \\
\hline Media & 60.00 \\
\hline Mode & 45 \\
\hline Std. Deviasi & 15.730 \\
\hline Minimum & 40 \\
\hline Maximum & 95 \\
\hline N & 55 \\
\hline
\end{tabular}

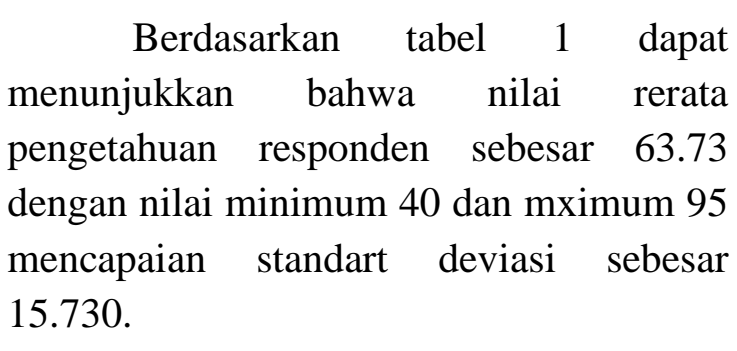


Karakteristik Responden Berdasarkan Pengetahuan Ibu tentang Imunisasi Difteri pada semua indikator pengetahuan.

Tabel 2. Karakteristik Responden Berdasarkan Pengetahuan Ibu tentang Imunisasi Difteri pada semua indikator pengetahuan di Puskesmas Jatiwates Kecamatan Tembelang Kabupaten Jombang.

\begin{tabular}{|l|r|r|r|r|r|r|r|r|}
\hline $\begin{array}{l}\text { Penge- } \\
\text { tahuan }\end{array}$ & $\begin{array}{c}\text { Penger- } \\
\text { tian }\end{array}$ & $\begin{array}{c}\text { Tanda } \\
\text { gejala }\end{array}$ & $\begin{array}{c}\text { Penular } \\
\text {-an }\end{array}$ & $\begin{array}{c}\text { Masa } \\
\text { Inku- } \\
\text { basi }\end{array}$ & $\begin{array}{c}\text { Faktor } \\
\text { Resiko }\end{array}$ & $\begin{array}{c}\text { Kompli- } \\
\text { kasi }\end{array}$ & $\begin{array}{c}\text { Penceg } \\
\text { ahan }\end{array}$ & $\begin{array}{c}\text { Obat- } \\
\text { obatan }\end{array}$ \\
\hline Mean & 71.82 & 60.00 & 60.90 & 60.00 & 66.36 & 63.64 & 66.36 & 60.91 \\
\hline Median & 50.00 & 50.00 & 50.00 & 50.00 & 50.00 & 50.00 & 75.00 & 75.00 \\
\hline Mode & 50 & 100 & 50 & 50 & 50 & 50 & 75 & 75 \\
\hline $\begin{array}{l}\text { Std. } \\
\text { Deviasi }\end{array}$ & 28.486 & 40.14 & 36.882 & 36.515 & 31.993 & 31.113 & 25.558 & 26.248 \\
\hline Minimum & 0 & 0 & 0 & 0 & 0 & 0 & 0 & 0 \\
\hline Maximum & 100 & 100 & 100 & 100 & 100 & 100 & 100 & 100 \\
\hline $\mathrm{N}$ & 55 & 55 & 55 & 55 & 55 & 55 & 55 & 55 \\
\hline
\end{tabular}

Berdasarkan hasil penelitian diatas dapat diketahui bahwa hasil pengetahuan ibu tentang imunisasi difteri pada anak balita dari 55 sampel sesuai indikator menunjukkan nilai rerata pada pengertian didapatkan 71.82, tanda gejala 60.00, penularan 60.90, masa inkubasi 60.00, faktor resiko 66.36, komplikasi 63.64, pencegahan 66.36, obat-obatan 60.91. Untuk standard deviasi didapatkan pengertian 28.486, tanda gejala 40.139, penularan 36.882 , masa inkubasi 36.515 , faktor resiko 31.933, komplikasi 31.113, pencegahan 25.558, dan obat-obatan 26.248 .

\section{Karakteristik Responden Berdasarkan Sikap Ibu tentang Imunisasi Difteri.}

Berdasarkan tabel 3 dapat menunjukkan bahwa nilai rerata pengetahuan responden sebesar 50.01 dengan nilai minimum 38 dan mximum 74 mencapaian standart deviasi sebesar 10.000
Tabel 3. Karakteristik Responden Berdasarkan Sikap Ibu tentang Imunisasi Difteri di Puskesmas Jatiwates Kecamatan Tembelang Kabupaten Jombang.

\begin{tabular}{|l|r|}
\hline \multicolumn{1}{|c|}{ Sikap } & \\
\hline Mean & 50.01 \\
\hline Media & 47.50 \\
\hline Mode & 42 \\
\hline Std. Deviasi & 10.000 \\
\hline Minimum & 38 \\
\hline Maximum & 74 \\
\hline N & 55 \\
\hline
\end{tabular}

Karakteristik Responden Berdasarkan Sikap Ibu tentang Imunisasi Difteri pada semua indikator pengetahuan.

Tabel 4. Karakteristik Responden Berdasarkan Pengetahuan Ibu tentang Imunisasi Difteri pada semua indikator pengetahuan di Puskesmas Jatiwates Kecamatan Tembelang Kabupaten Jombang.

\begin{tabular}{|l|r|r|r|r|}
\hline \multicolumn{1}{|c|}{ Sikap } & Menerima & Merespon & Menghargai & $\begin{array}{c}\text { Bertanggung- } \\
\text { jawab }\end{array}$ \\
\hline Mean & 50.00 & 49.99 & 49.99 & 49.99 \\
\hline Median & 45.00 & 48.60 & 46.30 & 47.30 \\
\hline Mode & 42 & 40 & 43 & 44 \\
\hline Std. Deviasi & 9.984 & 10.006 & 10.017 & 9.984 \\
\hline Minimum & 39 & 40 & 38 & 36 \\
\hline Maximum & 72 & 81 & 75 & 71 \\
\hline N & 55 & 55 & 55 & 55 \\
\hline
\end{tabular}

Dari tabel 4 diketahui bahwa hasil sikap ibu tentang imunisasi difteri pada anak balita dari 55 sempel sesuai indikator menunjukkan nilai rerata pada menerima 50.00, merespon 49.99, menghargai 49.99, bertanggungjawab 49.99. Untuk standard deviasi didapatkan menerima 9.984 merespon 10.006, menghargai 10.017, bertanggung jawab 9.984 . 
Hubungan pengetahuan dengan sikap ibu tentang imunisasi difteri pada anak balita di Desa Jatiwates Kecamatan Tembelang Kabupaten Jombang.

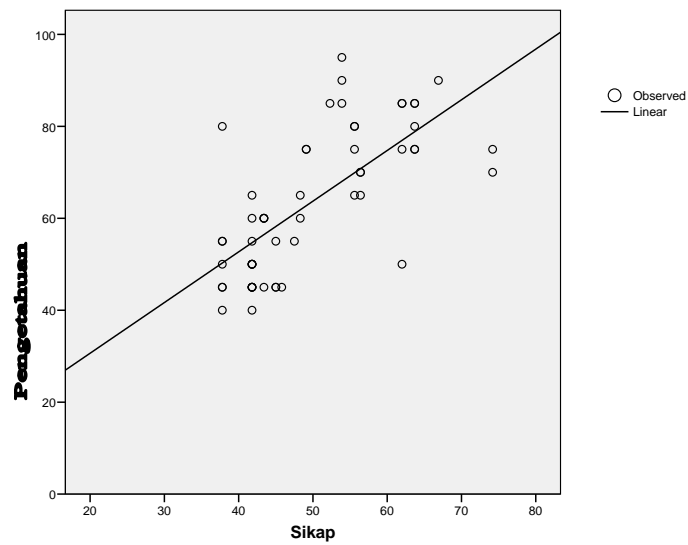

Gambar 1. Garis linear hubungan pengetahuan dengan sikap ibu tentang imunisasi difteri pada anak balita di Desa Jatiwates Kecamatan Tembelang Kabupaten Jombang.

Dari gambar linier diatas dapat dilihat bahwa y cenderung membesar apabila $\mathrm{x}$ membesar, maka korelasinya disebut korelasi positif antara pengetahuan dengan sikap, hubungan pengetahuan dengan sikap ibu tentang imunisasi difteri pada anak balita menunjukkan nilai signifikasi 0.000 yang menunjukkan bahwa korelasi antara pengetahuan dengan sikap ibu tentang imunisasi difteri adalah bermakna nilai korelasi 0.491 menunjukkan bahwa korelasi yang kuat. dengan perolehan nilai rerata bahwa nilai rerata pengetahuan responden sebesar 63.73 dengan nilai minimum 40 dan mximum 95 mencapaian standrt deviasi sebesar 15.730. Nilai rerata sikap responden sebesar 50.01 dengan nilai minimum 38 dan mximum 74 mencapaian standrt deviasi sebesar 10.000 .

Untuk menentukan jenis uji maka dilakukan uji normalitas untuk setiap variable, dari hasil uji normalitas untuk variable pengetahuan didapatkan hasil nilai signifikasi sebesar, 0.000 oleh karena nilai $p$ value $<0.05$ pada variable pengetahuan maka dapat diambil kesimpulan data tersebut berdistribusi tidak normal.

Dari hasil uji normalitas dari kedua variable didapatkan hasil bahwa data distribusi tidak normal maka yang semula akan menggunakan uji korelasi person karena data distribusi tidak normal, maka data tidak memenuhi syarat untuk menentukan uji korelasi pearson maka dipilih uji alternatifnya yaitu korelasi spearman rho.

\section{PEMBAHASAN}

\section{Pengetahuan Tentang Imunisasi Difteri}

Pengetahuan merupakan justified true believe. Seorang individu membenarkan (justifies) kebenaran atas kepercayaannya berdasarkan observasinya mengenai dunia. Jadi bila seseorang menciptakan pengetahuan, ia menciptakan pemahaman atas suatu suatu situasi baru dengan cara berpegang pada kepercayaan yang telah dibenarkan. Dalam definisi ini, pengetahuan merupakan konstruksi dari kenyataan, dibandingkan sesuatu yang benar secara abstrak. Penciptaan pengetahuan tidak hanya merupakan gabungan dari fakta-fakta, namun suatu proses yang unik pada manusia yang sulit disederhanakan atau ditiru. Penciptaan pengetahuan melibatkan perasaan dan sistem kepercayaan (belief sistems) dimana perasaan atau sistem kepercayaan itu bisa tidak disadari (Setiarso, 2011).

Hasil penelitian menunjukan bahwa pengetahun responden sebagian besar adalah kurang, pengetahuan kurang yang terdapat pada responden jika ditinjau darti segi indikator pengetahuan lebih di 
dominasi pada obat-obatan, responden justru lebih mengetahui jenis obat difteri dari pada pengertian difteri itu sendiri. hal ini di sebabkan oleh banyak Faktor yang mempengaruhi pengetahuan responden tentang difteri faktor tersebut diantaranya umur, pendidikan, pekerjaan, informasi, yang berdampak pada ketidak ikut sertaan masyarakat dalam imunisasi difteri.

Usia adalah umur yang terhitung mulai saat dilahirkan sampai saat ia akan berulang tahun. Semakin cukup umur, tingkat kematangan dan kekuatan seseorang akan lebih matang dalam berpikir dan bekerja. Dari segi kepercayaan masyarakat yang lebih dewasa akan lebih dipercaya dari pada orang yang belum cukup tinggi tingkat kedewasaannya. Hal ini sebagai akibat dari pengalaman dan kematangan jiwanya. pengetahuan yang didukung oleh lingkungan berdasarkan kematangan atau usia seseorang. Umur merupakan ukuran tingkat kedewasaan seseorang. Orang yang mempunyai umur produktif akan mempunyai daya pikir yang lebih rasional dan memiliki pengetahuan yang baik sehingga orang memiliki motivasi yang baik (Purwanto, 2010). Umur akan mempengaruhi tingkat kematangan seseorang. Umur orang yang produktif akan mempengaruhi pandangannya terhadap sesuatu hal yang baru yang datang dari luar sehingga pengetahuan yang dimiliki bertambah. Semakin bertambahnya umur seseorang maka orang tersebut semakin matang dalam berpikir secara rasional tentang pentingnya mengikuti inumisasi difteri.

Makin tinggi tingkat pendidikan seseorang maka makin mudah dalam menerima informasi, sehingga semakin banyak pula pengetahuan yang dimiliki. Sebaliknya pendidikan yang kurang akan menghambat perkembangan sikap seseorang terhadap nilai-nilai yang baru dikenal. Pendidikan klien dapat meningkatkan keteraturan, sepanjang bahwa pendidikan tersebut merupakan pendidikan yang aktif (Notoatmodjo, 2007). Pendidikan SMP merupakan pendidikan dasar dimana ibu mempunyai kemampuan dalam menyerap informasi yang kurang. Ibu sulit mencerna informasi yang diberikan oleh petugas kesehatan tentang pentingnya imunisasi difteri. Pendidikan dasar menyebabkan ibu mudah dipengaruhi lingkungan sekitar dalam melakukan pemeriksaan kehamilan, misalnya ibu menganggap tidak perlu melakukan pemeriksaan kehamilan pada awal kehamilan. pengetahuan seseorang sangat berkaitan dengan pendidikan. Hal ini dikarenakan semakin tinggi tingkat pendidikan seseorang maka semakin baik tinggi pula pengetahuan yang dimiliki. Pendidikan yang tinggi akan mempengaruhi pengetahuan secara internal seseorang untuk mengikuti pelaksanaan imunisasi difteri.

Pekerjaan adalah serangkaian tugas atau kegiatan yang harus dilaksanakan atau diselesaikan oleh seseorang sesuai dengan jabatan atau profesi masing-masing. Status pekerjaan yang rendah sering mempengaruhi motivasi seseorang sehingga mempengaruhi dukungan yang diberikan pada ibu (Notoatmodjo, 2010). Responden merupakan ibu rumah tangga sehingga kurang mendapatkan informasi dari dunia luar, adapaun ibu rumah tangga sering mendapatkan informasi dari tetangga atau masyarakat awam. sehingga pengetahuan yang dimilikinya dalam kategori kurang, hal ini diketahui bahwa dari 19 responden yang tidak bekerja (IRT) 
sebagian besar berpengetahuan kurang sebanyak $73,7 \%$.

Sikap akan lebih mudah terbentuk apabila pengalaman pribadi tersebut terjadi dalam situasi yang melibatkan emosi, perasaan, pengalaman akan lebih mendalam dan lama membekas pengalaman masa lalu merupakan sumber pengetahuan yang dapat di jadikan acuan untuk memperbaiki prilaku seseorang. Pengalaman memberikan makna tersendiri bagi seseorang, ibu hamil yang belum pernah memiliki pengalaman/baru memiliki anak 1 akan sangat hati-hati dalam menjaga kondisi anaknya yang sehingga ibu cenderung untuk melakukan imunisasi difteri.

$\begin{array}{rrr}\text { Informasi } & \text { adalah keseluruhan } \\ \text { makna, dapat diartikan sebagai }\end{array}$ pemberitahuan seseorang, biasanya dilakukan oleh tenaga kesehatan. Pendekatan ini biasanya digunakan untuk menggugah kesadaran masyarakat terhadap suatu inovasi yang berpengaruh terhadap perilaku, biasanya melalui media massa (Saifudin, A, 2005). Tingkat pendidikan ibu yang mayoritas dasar, sehingga sulit menyerap informasi skaligus mengaplikasikan dalam bentuk tindakan. Atau bisa jadi ibu pada dasarnya ibu yang sudah memahami tentang imunisasi difteri. Akan tetapi, adanya adanggapan bahwa ibu sehat jadi tidak perlu melakuakan imunisasi difteri.

\section{Sikap Tentang Iminisasi Difteri}

Hasil penelitian menunjukkan bahwa sebagian besar sikap responden adalah negatif. Banyaknya responden yang mempunyai sikap negatif dikarenakan sebagian besar responden belum dan kurang mengenal tentang imunisasi difteri. Responden hanya sebatas tahu apa itu imunisasi, tetapi mereka tidak mengetahui pentingnya mendapatkan imunisasi difteri. Hasil penelitian menunjukan bahwa sebagian besar responden berumur 20 - 30 tahun. Menurut Elisabeth (2005), usia adalah umur individu yang terhitung mulai saat dilahirkan sampai berulang tahun. Sedangkan menurut Huclok, semakin cukup umur, tingkat kematangan dan kekuatan seseorang akan lebih matang dalam berfikir dan bekerja. Dan segi kepercayaan masyarakat seseorang yang lebih dewasa dipercaya dan orang yang belum tinggi kedewasaannya. Hal ini akan sebagai dan pengalaman dan kematangan jiwa.

Responden yang berusia sebagian besar 20 - 30 tahun seharusnya mempunyai sikap yang positif tentang imunisasi difteri karena usia responden termasuk ke dalam usia reproduktif yang mana kemampuan berpikir responden sangat matang dan rasional terhadap sesuatu yang penting dan tidak penting. Akan tetapi hasil penelitian menunjukkan sebagian besar negatif karena responden takut dan khawatir jika anaknya di suntik, dan takut jika setelah diimunisasi badan si anak panas atau demam.

Pendidikan responden dapat mempengaruhi sikap, selama pendidikan itu merupakan pendidikan aktif, seperti penggunaan buku-buku dan berbagai media elektronik secara mandiri. Dimana pendidikan yang tinggi akan mempengaruhi daya serap dalam menerima informasi yang baru khususnya tentang imunisasi difteri (Niven, 2006). Semakin tinggi pendidikan seseorang semakin mudah menyerap informasi yang di aplikasikan dalam prilaku dalam hal ini peran sebagai orang tua. Responden yang berpendidikan tinggi akan memiliki peran yang baik dalam mengikuti imunisasi 
difteri, sebaliknya banyaknya responden yang berpendidikan dasar yaitu SMP menyebabkan responden kurang dapat menerima informasi yang diberikan oleh petugas kesehatan tentang imunisasi difteri.

Bekerja adalah upaya untuk memenuhi kebutuhan responden dengan dengan penghasilan yang baik akan meningkatkan taraf perekonomian yang di miliki suatu responden (Yohana, 2013). Responden yang bekerja petani menyebabkan responden tidak mempunyai kesempatan bertukar informasi dengan rekan kerja tentang pentingnya imunisasi difteri dan banyak responden yang lebih memilih untuk bekerja di sawah dibandingkan mengantarkan anaknya untuk mengikuti kegiatan imunisasi.

\section{Hubungan Pengetahuan dengan Sikap Ibu Tentang Imunisasi Difteri Pada Anak Balita}

Pengetahuan merupakan domain yang sangat penting untuk terbentuknya tindakan seseorang (overt behavior). Karena dari pengalaman yang didasari oleh pengetahuan akan lebih langgeng dibandingkan dengan perilaku yang tidak didasari oleh pengetahuan (Notoatmodjo, 2007).

Seseorang sikap negatif tentang difteri disebabkan karena orang tersebut tidak atau belum mengetahui tentang imunisasi difteri. Tetapi mungkin juga karena belum pernah mendapatkan penyuluhan tentang imunisasi difteri yang benar dari petugas kesehatan. Sebagian besar persepsi ibu tentang imunisasi difteri adalah negatif sehingga persepsi yang dimiliki akan mempengaruhi sikap ibu. Apabila ibu mengetahui tentang manfaat imunisasi difteri baik melalui media elektronik, media massa dan tenaga kesehatan maka ibu tersebut akan menerapkan persepsi yang dimilikinya kedalam tindakan nyata. sikap yang positif akan menanamkan dalam pikiran bahwa segala sesuatu itu penting apabila diterapkan.

Perilaku ibu dalam mengikuti imunisasi difteri ditentukan oleh pengetahuan, sikap, ketersediaan fasilitas, sikap dan perilaku para petugas kesehatan terhadap kesehatan juga akan mendukung dan memperkuat terbentuknya perilaku (Notoatmodjo, 2007).

Dari hasil penelitian didapatkan bahwa walaupun pengetahuan ibu kurang akan tetapi ibu memiliki sikap positif. Hal ini dikarenakan ibu didorong oleh petugas kesehatan, kader dan keluarga untuk mengimunisasikan difteri pada balitanya. Atas anjuran dari petugas kesehatan tersebut menyebabkan ibu mau datang ke posyandu untuk mendapatkan imunisasi difteri pada balita.

\section{SIMPULAN}

1. Pengetahuan ibu tentang imunisasi difteri hampir setengahnya adalah kurang

2. Sikap ibu tentang imunisasi difteri lebih dari setengahya adalah negatif

3. Ada hubungan pengetahuan dengan sikap ibu tentang imunisasi difteri pada anak balita di Desa Jatiwates Kecamatan Tembelang Kabupaten Jombang

\section{SARAN}

1. Bagi peneliti selanjutnya, melakukan penelitian tentang faktor yang mungkin mempengaruhi lemahnya motivasi ibu selain karakteristik umur, pendidikan dan paritas. 
2. Ibu dapat mengakses informasi tentang imunisasi difteri baik melalui media massa maupun media elektronik sehingga ibu mengerti dan mempunyai persepsi positif tentang imunisasi difteri dan dapat termotivasi untuk mengikuti imunisasi difteri.

3. Diharapkan meningkatkan penyuluhan tentang imunisasi difteri dan memberikan dorongan pada ibu tentang pentingnya mendapatkan imunisasi difteri.

\section{DAFTAR PUSTAKA}

1. Adriyanto. 2010. Imunisasi Difteri. Jakarta: Erlangga.

2. Azwar. 2008. Sikap Manusia. Jakarta.

3. Cahyani. 2011. Faktor yang mempengaruhi Difteri. http://www.info-cyberneth.com diakses tanggal 15 Desember 2014.

4. Colifah. 2010. Pencegahan Difteri. http://www.info-cyber-neth.com diakses tanggal 15 Desember 2014.

5. Dinkes Jatim. 2012. Angka Kejadian Difteri. http//:www.dinkesjati.go.id. Akses 23 November 2014.

6. Hidayat. 2009. Metode Penelitian Keperawatan dan tehnik Analisis Data. Jakarta: PT. Rineka Cipta.

7. Kholifah. 2010. Pandangan Masyarakat Tentang Difteri http//:www.cybersehat.com. Akses 2 November 2014.

8. Meliono. 2010. Mangement Pengetahuan. Jakarta: EGC.

9. Mujayanah. 2011. Bimbingan Dokter Pada Imunisasi Difteri. Jakarta: Dian Press.

10. Musayadah. 2012. Menaklukan Difteri dengan Imunisasi. Yogyakarta: Sakkhasukma.
11. Nasir. 2005. Metodelogi Penelitian. Bandung: Galiya.

12. Nazir, Mochamad. 2005. Metodelogi Penelitian. Bandung: Ghalia Pustaka Utama.

13. Notoatmodjo. 2010. Metodologi Penelitian Kesehatan. Jakarta: PT Rineka Cipta.

14. Notoatmodjo. 2012. Promosi Kesehatan Teori dan Aplikasi. Jakarta: PT Rineka Cipta.

15. Nursalam. 2003. Konsep Penerapan Metodologi Penelitian Ilmu Keperawatan. Jakarta: Salemba Medika.

16. Nursalam. 2008. Konsep Penerapan Metodologi Penelitian Ilmu Keperawatan. Jakarta: Salernba Medika.

17. Purwodarminto. 2008. Kamus Besar Bahasa Indonesia. Jakarta: Balai Pustaka.

18. Redja. 2010. Faktor Yang mempengaruhi Pengetahuan. http//www.smart info.com. Akses 23 Desember 2014.

19. Rianita. 2012. Difteri Pertusis. http//www.info_sehat.com. Akses 2 November 2014.

20. Setiadi. 2007. Metodologi penelitian. Yogyakarta: Nuha medika.

21. Setiarso. 2011. Pengetahuan, Sikap, Dan Perilaku. Jakarta: Numha Medika.

22. Sulistyawati. 2010. I.Jpaya Pencegahan Difteri. http//:www.intramedi.com akses 3 Januari 2014.

23. Sunaryo. 2010. Sikap Manusia. Bandung: Rosdakarya.

24. Sunaryo. 2008. Ilmu Perilaku. Jakarta: EGC.

25. Syaifudin. 2012. Pengukuran psikologis. Jakarta: EGC. 
26. Tambotoh. 2011. Ilmu Pengetahuan. Jakarta: EGC.

27. Yohana. 2012. Status Pekerjaan Sese orang dan Pengaruhnya Terhadap Kehidupan. www.unikom.ac.id diakses tanggal 05 Desember 2014.

Cite This Article As: Aprilia, R., Herlina, Idayanti, T., Virgia, V., Yuliani, A. Hubungan Pengetahuan Dengan Sikap Ibu Tentang Imunisasi Difteri Pada Anak Balita Di Desa Jatiwates Kecamatan Tembelang Kabupaten Jombang. Nurse and Health: Jurnal Keperawatan 2018; 7(1): $31-41$. 